\title{
Libocedroquinone: A Promising Anticancer Lead against Lung Cancer from Calocedrus Decurrens
}

\section{(๑) $\circledast \Theta$}

\author{
Authors \\ Santhi Subramanyan ${ }^{1,2}$, Varsha Karunakaran ${ }^{1,2}$, Selvakumar Deepika ${ }^{1}$, Anuja Joseph Gracy 1, 2, Veluthoor Sheeba ${ }^{3}$, \\ Karchesy Joseph4, Kaustabh Kumar Maiti1, 2, Ramavarma Luxmi Varma1, 2, Kokkuvayil Vasu Radhakrishnan, 2
}

\section{Affiliations}

1 Chemical Sciences and Technology Division, CSIR-National Institute for Interdisciplinary Science and Technology, Thiruvananthapuram, India

2 Academy of Scientific and Innovative Research (AcSIR), Ghaziabad, Uttar Pradesh, India

3 CoreValleys Herbal Technologies, Kozhikode, India

4 Wood Science and Engineering, Oregon State University, Corvallis, OR, USA

Key words

Calocedrus decurrens, Cupressaceae, libocedroquinone, cytotoxicity, lung cancer

received $\quad 08.07 .2021$

revised 08.10 .2021

accepted 09.11.2021

\section{Bibliography}

Planta Med Int Open 2022; 9: e54-e59

DOI 10.1055/a-1699-8748

ISSN 2509-9264

(c) 2022. The Author(s).

This is an open access article published by Thieme under the terms of the Creative Commons Attribution-NonDerivative-NonCommercial-License, permitting copying and reproduction so long as the original work is given appropriate credit. Contents may not be used for commecial purposes, or adapted, remixed, transformed or built upon. (https://creativecommons. org/licenses/by-nc-nd/4.0/)

Georg Thieme Verlag KG, Rüdigerstraße 14,

70469 Stuttgart, Germany

\section{Correspondence}

Dr. K. V. Radhakrishnan

Senior Principal Scientist

Chemical Sciences and Technology Division

CSIR-NIIST

Thiruvananthapuram-695019

India

Tel.: 91/471/2515 420

radhu@niist.res.in or radhu2005@gmail.com

$\Theta$ Supplementary material is available under https://doi.org/10.1055/a-1699-8748.

\begin{abstract}
A focus on evaluating anticancer potency of various extracts of the heartwood of Calocedrus decurrens against human lung adenocarcinoma (A549) cell line was performed using in vitro MTT assay. The hexane extract displayed excellent cytotoxic effect, and the phytochemical investigation of the hexane and acetone extracts resulted in the isolation of five major compounds. The structure of the compounds was established as libocedrol (1), thymoquinone (2), libocedroquinone (3), diethylphthalate (4), and (1 R, $2 R$, $4 R$ )-p-menthane-1,2,4-triol (5). Compounds 4 and 5 are reported for the first time from the Calocedrus genus. Compounds $\mathbf{1 - 3}$ were evaluated for their cytotoxicity against the lung cancer cell line along with a healthy control. Compound $\mathbf{3}$ was more potent than other compounds against the $A 549$ cell line with an $\mathrm{IC}_{50}$ of $4.8 \mu \mathrm{M}$ at $24 \mathrm{~h}$. Moreover, compound $\mathbf{3}$ exhibited less toxicity with the normal lung fibroblast cell line WI-38. This is the first anticancer study of the species Calocedrus decurrens.
\end{abstract}

\section{Introduction}

Cupressaceae is the largest conifer family with worldwide distribution. It consists of 32 genera, and the members of this family are highly valued for their timber, resin, fruit, and ornamentals [1,2]. The genus Calocedrus belongs to the cypress family and is native to eastern Asia and North America. Calocedrus mainly includes 4 species viz., Calocedrus decurrens, Calocedrus macrolepis, Calocedrus formosana, and Calocedrus rupestris [3,4]. These evergreen coniferous trees were primarily cultivated for ornamental purposes or lumber industry. Conifers are also renowned for their ability to produce an enormous array of bioactive molecules, leading to the discovery of new drugs. Calocedrus macrolepis and C. formosana are well-studied species in this genus and are reported to possess antioxidant, antiradical, antifungal, antimicrobial, anticancer, and immuno-activating properties [5-10]. The chemical constituents of these plants include lignans, sesquiterpenes, diterpenoids, terpenoids, abietane-O-abietane type dimers, labdane diterpenes, and phaeophorbides [5, 8, 11-13]. Calocedrus rupestris is only recorded in Vietnam and is considered a rare and endemic species [4]. 
Calocedrus decurrens (Torr.) Florin, commonly known as the "Incense cedar tree," is indigenous to the United States' Pacific region, such as Oregon and California [14]. The essential oil of cedarwood is highly aromatic and contains phenolic terpenes as major constituents. The heartwood was reported to contain carvacrol, thymoquinone, $p$-methoxythymol, $p$-methoxycarvacrol, libocedrol, heyderiol, calocedrol A, and calocedrol B [15-17]. Von Rudloff identified the main constituents of leaf essential oil as limonene (31.3\%), $\Delta$-3-carene (21.0\%), $\alpha$-pinene (9.2\%), myrcene (8.0\%), and $\alpha$ terpenyl acetate (5.7\%) [18]. Veluthoor et al. reported that the essential oil of the heartwood contains thymoquinone (35.9\%), carvacrol (29.2\%), p-methoxythymol (11.0\%), and p-methoxycarvacrol (3.2\%) as the major constituents [19]. Garcia et al. reported 4 unusual pinane derivatives: pin-2-en-8-al, pin-2-en-8-ol, pin-2-en8-yl acetate, and methyl pin-2-en-8-oate from the essential oil in young branches of $C$. decurrens[20]. The extracts and essential oil of the heartwood exhibited antifungal, antimicrobial, and biocidal activity, which supports the decay-resistant nature of the wood [21-23]. Native Americans used the decoction of cedar leaves for stomach trouble, as a vapor infusion for colds and as a food spice [24]. The wood's durable and decay-resistant nature made it unique in the lumber industry, especially for making pencils and general building purposes.

From the literature review, only a few reports were available regarding the phytochemistry and pharmacology of the species $C$. decurrens. Our study mainly focused on the phytochemical investigation of the heartwood to identify its constituents, with particular emphasis on the anticancer property of the extracts and compounds. To the best of our knowledge, this is the first report on the anticancer activity of $C$. decurrens.

\section{Results and Discussion}

About $1 \mathrm{~kg}$ of the heartwood of $C$. decurrens was extracted with hexane, acetone and ethanol. The extracts were assessed for their cytotoxicity against human lung adenocarcinoma (A549) cell lines using MTT assay. Doxorubicin was used as the standard, and the results are shown in $>$ Table 1 . The effect of various concentrations of the extracts is depicted in $>$ Fig. 1 . The hexane extract showed excellent activity with an $\mathrm{IC}_{50}$ value $<5 \mu \mathrm{g} / \mathrm{mL}$, which was comparable with the control doxorubicin at $24 \mathrm{~h}\left(\mathrm{IC}_{50} 1.63 \mu \mathrm{g} / \mathrm{mL}\right)$ as well as $48 \mathrm{~h}\left(\mathrm{IC}_{50}\right.$ $1.18 \mu \mathrm{g} / \mathrm{mL}$ ). The acetone extract exhibited good activity with an $\mathrm{IC}_{50} 11.26 \mu \mathrm{g} / \mathrm{mL}$, while the ethanol extract was least toxic with an $I C_{50}$ value $>100 \mu \mathrm{g} / \mathrm{mL}$ at $24 \mathrm{~h}$. Since hexane and acetone extracts demonstrated good inhibitory activity, further phytochemical investigation was focused on these extracts. Hence, the present work describes the successive isolation and purification of phytoconstituents from the hexane and acetone extracts of the heartwood of $C$. decurrens and their antiproliferative study toward human lung adenocarcinoma (A549) and normal lung fibroblast (WI-38).

Phytochemical investigation of the heartwood of $C$. decurrens resulted in the isolation of 5 compounds viz: libocedrol (1) [17], thymoquinone (2) [25], libocedroquinone (3) [17], diethylphthalate (4) [26], and (1R, 2R, 4R)-p-menthane-1,2,4-triol (5) [27]. The structure of the compounds ( $>$ Fig. 2 ) was established by extensive spectroscopic analysis and on comparison of their spectral data with those in the literature (see Supporting Information). Libocedroqui-
- Table 1 Cytotoxicity data for different extracts in A549 over a time of 24 and $48 \mathrm{~h}$.

\begin{tabular}{|c|c|c|}
\hline \multirow[t]{3}{*}{ Extracts } & \multicolumn{2}{|c|}{$\mathrm{IC}_{50}$ of extracts in $\mu \mathrm{g} / \mathrm{mL}$} \\
\hline & \multicolumn{2}{|c|}{ A549 } \\
\hline & $24 h$ & $48 \mathrm{~h}$ \\
\hline Hexane & $<5$ & $<5$ \\
\hline Acetone & $11.26 \pm 0.01^{b}$ & $6.09 \pm 0.01^{b}$ \\
\hline Ethanol & $>100^{c}$ & $37.16 \pm 0.08^{b}$ \\
\hline Doxorubicina & $1.63 \pm 0.22^{b}$ & $1.18 \pm 0.16^{b}$ \\
\hline \multicolumn{3}{|c|}{$\begin{array}{l}\text { a Standard drug; }{ }^{b} \text { statistical significance: doxorubicin vs. extracts } \\
\mathrm{p}<0.001 ;{ }^{c} \mathrm{IC}_{50} \text { not achieved. A549: human lung adenocarcinoma. }\end{array}$} \\
\hline
\end{tabular}

none was isolated as a reddish crystalline solid, and the structure was further supported with a single-crystal XRD ( for 3 (CCDC 2086733): $\mathrm{C}_{21} \mathrm{H}_{26} \mathrm{O}_{4} \cdot \mathrm{M}=342.42$, Triclinic, space group $\mathrm{P}-1, \mathrm{a}=8.666(5) \AA, \mathrm{b}=9.634(6)(3) \AA, c=13.266(8) \AA, \alpha=108.260(1$ $0)^{\circ} \beta=90.060(4)^{\circ}, y=110.285(10)^{\circ}$, cell formula units $Z=2$, crystal density $=1.162 \mathrm{mg} / \mathrm{m3}, \mathrm{T}=302(2), 3503$ reflections collected, [1505 reflections with $\mathrm{I}>2 \mid \mathrm{s}(\mathrm{I})] \mathrm{R}$ factor $\mathrm{gt} 0.0872$. The single crystal $X$-ray structure of this compound is being reported for the first time. Compounds 1-3 were previously reported by Zavarin et al. from this species [14-16]. This is the first report on the presence of compounds 4 and 5 in the Calocedrus genus. (1 R, 2 R,4R)-p-menthane-1,2,4triol was previously reported from Artemisia suksdorfi (Asteraceae family) and Daucus carota (Apiaceae family) [27, 28].

There are no reports available regarding the cytotoxicity of the 2 compounds, libocedrol and libocedroquinone. Therefore, compounds 1-3 were examined for their growth inhibitory properties against $\mathrm{A} 549$ and WI-38 cell lines. The standard drug used was doxorubicin (DOX), with similar concentrations as the compounds. Treatment of each compound resulted in a concentration-dependent reduction of cell viability. The cytotoxicity results in terms of $I C_{50}$ values are depicted in $\triangleright$ Table 2 , and the effect of various concentrations is represented in $>$ Fig. $\mathbf{4}$. Compounds $\mathbf{1}$ and $\mathbf{3}$ showed an IC $\mathrm{C}_{50}$ value of 7 and $4.6 \mu \mathrm{M}$ for $24 \mathrm{~h}$ and 7.2 and $3 \mu \mathrm{M}$ for $48 \mathrm{~h}$, respectively. Compound 2 did not produce any $I C_{50}$ effect $(>20 \mu \mathrm{M})$ in $24 \mathrm{~h}$ of incubation, whereas an $\mathrm{IC}_{50}$ value of $16.5 \mu \mathrm{M}$ was obtained in $48 \mathrm{~h}$. Doxorubicin showed $\mathrm{IC}_{50}$ at $1.8 \mu \mathrm{M}$ in $24 \mathrm{~h}$ and $0.8 \mu \mathrm{M}$ in $48 \mathrm{~h}$. Compounds 1 and 3 exhibited similar cytotoxic effects of doxorubicin upon $48 \mathrm{~h}$ of treatment ( $p>0.05$, non-significant when compared to doxorubicin, compound $\mathbf{1}$ and $\mathbf{3}$ ). Whereas in terms of $\mathrm{IC}_{50}$ value, compound 3 is found to be more efficient when compared to other compounds. Upon $24 \mathrm{~h}$ treatment, the $\mathrm{IC}_{50}$ value of compound 3 in the $\mathrm{A} 549$ cell line was $4.6 \pm 0.9 \mu \mathrm{M}$, whereas, for $\mathrm{WI}-38$, the $I C_{50}$ value was not achieved even at a concentration of $20 \mu \mathrm{M}$, emphasizing its minimal cytotoxic effects in normal cells. Even though these compounds are not as effective as doxorubicin against the human lung adenocarcinoma cell line, they exhibited low toxicity against the normal cell line, which was comparable with doxorubicin $(16.5 \mu \mathrm{M})$ at $24 \mathrm{~h}$.

Out of the selected compounds, compound 3 exhibited appreciable apoptotic effects toward the lung adenocarcinoma cells (A549) and was found to be least toxic to normal lung fibroblast cells (WI-38) at the specified concentration. The apoptotic ability of compound 3 was further demonstrated by using ethidium bromide-acridine orange live dead assay. In the dual staining proce- 
a

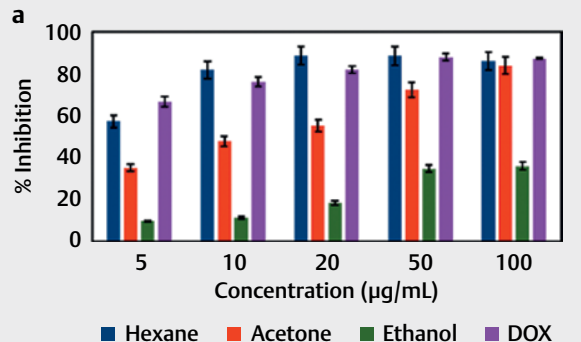

b

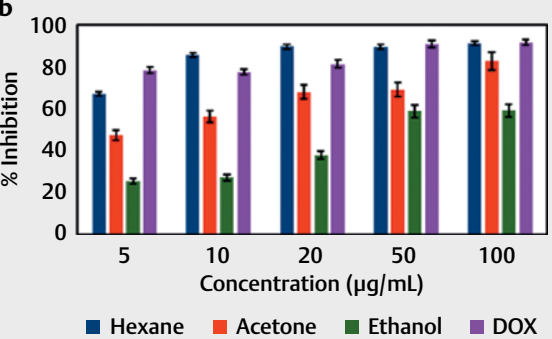

- Fig. 1 Evaluation of cytotoxicity of extracts by MTT assay on A549 cells (a) at $24 \mathrm{~h}$ and (b) at $48 \mathrm{~h}$.

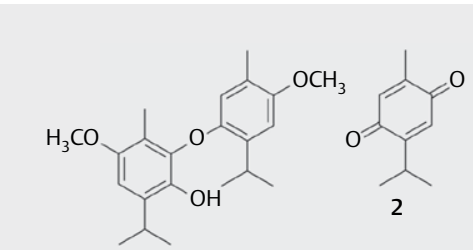

1

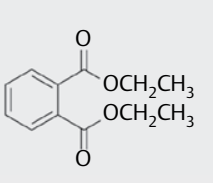

4

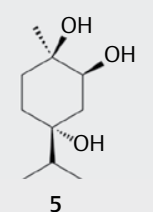

- Fig. 2 Chemical structure of compounds (1-5) isolated from C. decurrens.

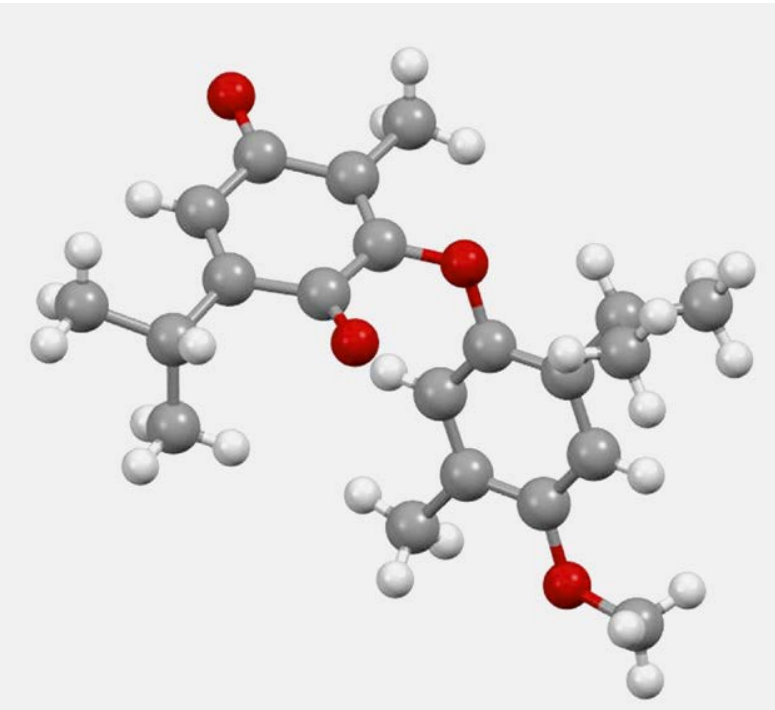

Fig. 3 ORTEP diagram of Libocedroquinone (3).

dure, ethidium bromide is impermeant to the cell membrane and only enters the dead cells with damaged cell membrane; it indicates red fluorescence upon intercalation with DNA. Acridine orange is a nonfluorescent membrane-permeable dye that becomes fluorescent upon conversion with the presence of cellular esterase enzymes, causing the live cells to appear green in color. Fluorescent images showed a reduced number of cells in compound 3 treated group in the live dead assay, with a high proportion of cells exhibiting yellow/red fluorescence compared with the untreated control cells ( $\vee$ Fig. 5). Thus, the results demonstrated the apoptotic-inducing ability of compound 3 even at $4.6 \mu \mathrm{M}$ concentration.

As per our study, libocedrol and libocedroquinone exhibited significant anticancer potency compared to compound $\mathbf{2}$ (i.e., thymoquinone [TQ]). TQ is the main constituent in black cumin (Nigella sativa, Ranunculaceae family) seed oil and is well known for its anticancer properties. TQ exerts excellent anticancer effects on various cancer cell lines, including pancreatic, uterine sarcoma, cervical, colon, lung, prostate, breast, myeloblastic leukemia, etc. [29, 30]. Previous reports revealed that TQ stimulated apoptosis in A549 lung cancer cells via p53 and caspase cascade-dependent pathway activation [31,32]. Yang et al. have shown that TQ significantly inhibited proliferation, migration, and invasion of A549 cells in a time- and dose-dependent manner by suppressing the ERK $1 / 2$ pathway in A549 cells [33]. Banerjee et al. reported that the synthetic analogs of TQ exhibited more potent anticancer potential than the parent TQ in terms of inhibition of cell growth and induction of apoptosis [34]. Considering the biosynthetic pathway, libocedroquinone is derived from the oxidative coupling of thymoquinone and $p$-methoxythymol [22]. As a structural derivative of thymoquinone, it exhibits excellent activity than thymoquinone toward cancer cells and is less toxic to normal cells. Our findings suggested that libocedroquinone could be developed as an effective chemotherapeutic agent for lung cancer. More studies are needed to uncover the exact molecular targets and mechanism of the action of libocedroquinone.

In summary, the current study was designed to evaluate the anticancer potency of various extracts and isolated compounds from the heartwood of Calocedrus decurrens. Five compounds were isolated from the heartwood extracts of $C$. decurrens, and compounds $\mathbf{4} \& \mathbf{5}$ were reported for the first time from this genus. In addition, the in vitro cytotoxic analysis of compounds $\mathbf{1 - 3}$ in human lung adenocarcinoma and normal lung fibroblast cell lines was conducted. Even though not up to the standard drug, libocedroquinone (3) showed satisfactory antiproliferative activity with minimal toxicity toward normal cells at $24 \mathrm{~h}$ incubation. To the best of our knowledge, this is the first anticancer study of the species $C$. decurrens. Our results suggested that libocedroquinone could be a potential candidate as an anticancer agent against lung cancer, and further investigations are necessary to validate its activity. 


\section{Materials and Methods}

\section{General experimental procedure}

The NMR spectra were acquired with Bruker Avance II AMX $500 \mathrm{MHz}$ spectrometer; NMR solvents used were $\mathrm{CDCl}_{3}$ and acetone- $\mathrm{d} 6$ with $0.03 \%$ tetramethylsilane (TMS) as the internal standard. Mass spectra were measured using Thermo Scientific Exactive mass spectrometer under ESI/HRMS at 60,000 resolutions. Silica gel (230-400 mesh and 100-200 mesh) and Sephadex LH-20 were used for column chromatography. All the chemicals and solvents used were purchased from Sigma Aldrich and Merck. The diffraction data of single crystals were collected on a Rigaku Saturn 724 + diffractometer using graphite monochromated Mo-Ka radiation.

\section{Plant material}

Incense cedar (Calocedrus decurrens) trees were identified and collected by Dr. Richard Halse, OSU herbarium director, from a logging and sawmill operations near Warm Springs, Jefferson, Oregon, USA. A voucher specimen was deposited in the Oregon State University Herbarium (Voucher number OSC228848). The heartwood was removed and shavings made and stored in vacuum-sealed containers at $-20^{\circ} \mathrm{C}$.

- Table $2 \mathrm{IC}_{50}$ values of different compounds in A549 and WI-38 cell lines at $24 \mathrm{~h}$ and $48 \mathrm{~h}$. Average of more than three independent experiments.

\begin{tabular}{|c|c|c|c|c|}
\hline \multirow[t]{3}{*}{ Compounds } & \multicolumn{4}{|c|}{$\mathrm{IC}_{50}$ of Compounds in $\mu \mathrm{M}$} \\
\hline & \multicolumn{2}{|c|}{ A549 } & \multicolumn{2}{|c|}{ WI-38 } \\
\hline & $24 \mathrm{~h}$ & $48 \mathrm{~h}$ & $24 h$ & $48 \mathrm{~h}$ \\
\hline 1 & $7 \pm 1.5^{b}$ & $7.2 \pm 0.3^{b}$ & $16.2 \pm 1.6$ & $11.4 \pm 2.6^{b}$ \\
\hline 2 & $>20^{c}$ & $16.5 \pm 1.2^{b}$ & $>20^{c}$ & $14.4 \pm 1.7^{b}$ \\
\hline 3 & $4.6 \pm 0.9^{b}$ & $3 \pm 0.2^{b, d}$ & $>20^{c}$ & $5.6 \pm 1.2^{d}$ \\
\hline Doxorubicina $^{a}$ & $1.8 \pm 0.2$ & $0.8 \pm 0.1$ & $16.5 \pm 0.5$ & $4.2 \pm 0.8$ \\
\hline \multicolumn{5}{|c|}{$\begin{array}{l}\text { a Standard drug; b }{ }^{2} \text { statistical significance: doxorubicin vs. compounds } \\
\text { p<0.001; }{ }^{C} I C_{50} \text { not achieved; }{ }^{d} \text { compound } 1 \text { vs. compound } 3 \text { p }<0.001 \text {; } \\
\text { A549: human lung adenocarcinoma; WI-38: normal lung fibroblast. }\end{array}$} \\
\hline
\end{tabular}

\section{Extraction and isolation}

About $1 \mathrm{~kg}$ of the heartwood shavings of the plant material was soaked in $5 \mathrm{~L}$ hexane for 3 days at room temperature. The supernatant liquid was decanted and filtered. The procedure was repeated three times, giving $11 \mathrm{~g}$ of the crude hexane extract. The residue obtained after extraction was further extracted with acetone and ethanol, which yielded $28 \mathrm{~g}$ of acetone and $17 \mathrm{~g}$ of ethanol extract. All the crude extracts were evaluated for cytotoxicity using an MTT assay. Further, the crude hexane extract was then fractionated on a silica gel (100-200 mesh) column and eluted with ethyl acetate in hexane gradient, increasing the amount of ethyl acetate to rise polarity. The elution was started with hexane and gradually increased the polarity (between 5 to $30 \%$ ), finally with $30 \%$ ethyl acetate/hexane. A total of 25 fractions of approximately $150 \mathrm{~mL}$ each were collected. Fractions collected were pooled into 3 fraction pools after analyzing the TLC. Fraction pool F2 (3.04 g) showed highly UV active spots. These fractions were purified successively with silica gel column chromatography in $5 \%$ ethyl acetate/hexane gradient to afford compound $\mathbf{1}$ (500 mg, purity $>95 \%$, from NMR) and 2 ( $563 \mathrm{mg}$, purity $>95 \%$, from NMR). Another subfraction $(100 \mathrm{mg})$ of F2 was rechromatographed on silica gel (230-400 mesh), a reddish compound with some minor impurities was obtained. It was further purified with Sephadex LH-20 in methanol yielded compound 3 ( $27 \mathrm{mg}$, purity $>95 \%$, from NMR). Next, we carried out the column chromatographic separation of the acetone extract. About $28 \mathrm{~g}$ of the acetone extract was subjected to silica gel CC (100-200 mesh) afforded two more compounds along with compounds $\mathbf{1}$ and $\mathbf{2}$. The elution was started with hexane, and an increase in polarity was carried out by increasing the amount of ethyl acetate (between 5 to $100 \%$ ). Final elution was carried out with ethyl acetate. As in the previous procedure, a total of $52 \mathrm{frac}-$ tions of approximately $250 \mathrm{~mL}$ each were collected. From their similarity in TLC, collected fractions were combined into 5 fraction pools (F1-F5). Compound 4 was obtained from the fraction pool $\mathrm{F} 2$ as a colorless oily substance $(17 \mathrm{mg})$ by eluting the column with
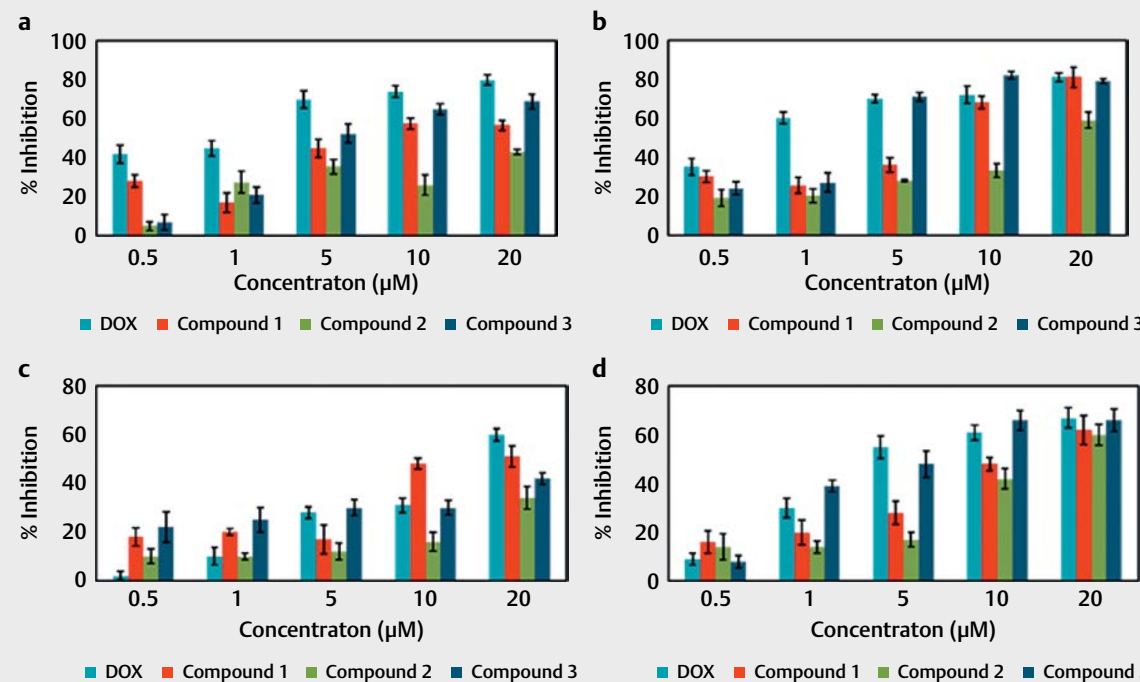

d

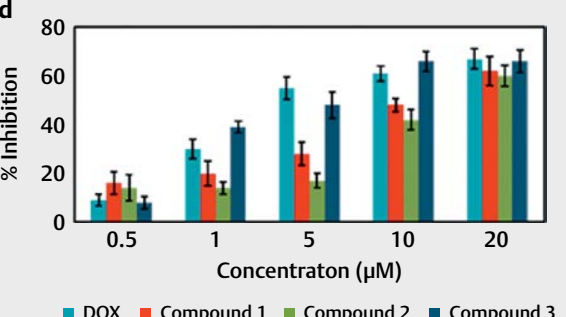

- Fig. 4 Evaluation of cytotoxicity of compounds by MTT assay on A549 (a) at 24h, (b) at $48 \mathrm{~h}$, and on WI-38 (c) at $24 \mathrm{~h}$ and (d) at $48 \mathrm{~h}$. 

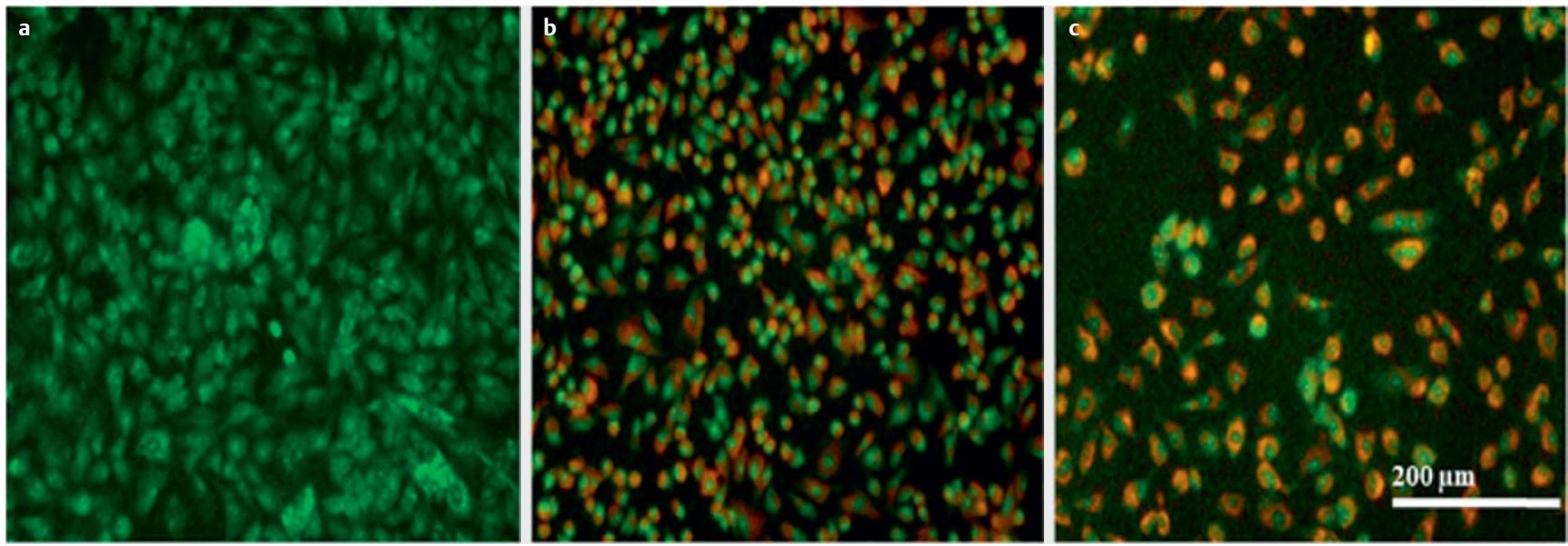

- Fig. 5 Induction of apoptosis by live-dead assay (a) control (b) A549 cells treated with compound $\mathbf{3}$ at $4.6 \mu \mathrm{M}$ (c) doxorubicin at $2.16 \mu \mathrm{M}$. Scale bar corresponds to $200 \mu \mathrm{m}$.

$5 \%$ ethyl acetate-hexane polarity. Compound $\mathbf{5}$ isolated from fraction pool F4 as a white crystalline solid ( $30 \mathrm{mg}, 90 \%$ EtOAc-hexane). The chemical structures of the compounds were characterized using various spectroscopic techniques.

\section{Cell lines and cultural conditions}

A549 (human lung adenocarcinoma) and WI-38 (human normal lung fibroblast) were obtained from National Centre for Cell Science (NCCS), Pune, India, after short tandem repeat (STR) profiling. The cell lines were cultured in DMEM supplemented with $10 \%$ heat-inactivated FBS and $1 \%$ antibiotics antimycotic solution (10,000 $\mathrm{U}$ Penicillin, $10 \mathrm{mg}$ streptomycin and $25 \mu \mathrm{g}$ amphotericin $\mathrm{B}$ per $\mathrm{mL}$ in $0.9 \%$ normal saline) in a humidified $\mathrm{CO}_{2}$ incubator at $37^{\circ} \mathrm{C}$ with $5 \% \mathrm{CO}_{2}$.

\section{Cytotoxicity assay}

The cytotoxicity effects of the extracts and the isolated compounds from Calocedrus decurrens were evaluated using the MTT assay [35]. Doxorubicin hydrochloride was used as the standard (D1515, Sigma-Aldrich, 98.0-102.0\%, HPLC purified). Mitochondrial dehydrogenase enzyme in the live cell will convert the tetrazolium salt into soluble formazan crystals whose absorbance can be measured at $570 \mathrm{~nm}$. The cells were seeded at a density of 10000 cells per well in $100 \mu \mathrm{L}$ volume with complete DMEM medium in 96-multiwell flat-bottom microtiter plates and incubated at $37^{\circ} \mathrm{C}$ with $5 \% \mathrm{CO}_{2}$ for $24 \mathrm{~h}$ for cells to adhere. Cells were then treated with different compounds having concentrations ranging from 0.5 to $20 \mu \mathrm{M}$ followed by further incubation for $24 \mathrm{~h}$ and $48 \mathrm{~h}$ separately. $100 \mu \mathrm{L}$ MTT solution $(0.5 \mathrm{mg} / \mathrm{mL}$ in HBSS) was added to each well and incubated for $3 \mathrm{~h}$. The solution was subsequently removed from wells, and resulting formazan crystals were solubilized in $100 \mu \mathrm{L}$ DMSO. Culture plates were rocked gently for $20 \mathrm{~min}$ to solubilize the crystals, and optical density was recorded spectrophotometrically using a microplate reader (BioTek) at $570 \mathrm{~nm}$. The relative cell viability in percentage was calculated using the formula: [Absorbance of treated/Absorbance of control] $\times 100$. As a result of cytotoxicity, the inhibition rate is calculated as Inhibition $\%=100$ - Viability $\%$.
Also, concentrations providing inhibition of $50 \%$ on cell growth $\left(\mathrm{IC}_{50}\right)$ were calculated.

\section{Live dead assay to determine apoptotic cells}

The most effective compound with the minimal IC $C_{50}$ value at $24 \mathrm{~h}$ from the MTT assay was carefully chosen for further screening. Staining with acridine orange and ethidium bromide dual dye is one of the most frequently used method for detecting apoptotic cells, where the varying uptake of 2 dyes by live and dead cells are observed [36]. In order to perform the assay, A549 cells were cultured at a seeding density of 5000 cells/well and treated with and without compound 3. A dual-staining dye cocktail was prepared by adding $1 \mu \mathrm{L}$ each acridine orange and ethidium bromide from $5 \mathrm{mg} /$ $\mathrm{mL}$ and $3 \mathrm{mg} / \mathrm{mL}$ stock, respectively, to $1 \mathrm{~mL}$ PBS buffer. One hundred $\mu \mathrm{L}$ of the as-prepared reagent was added to the compound 3 treated and untreated control cells. After incubation for $5 \mathrm{~min}$, the cells were then washed thrice with PBS buffer and observed under a fluorescence microscope (Nikon Eclipse TS100, Japan).

\section{Statistical analysis}

All data were acquired from 3 independent experiments. The results were provided as mean \pm standard deviation. The statistical analysis was performed by the software GraphPad Instat 2. Concentrations inducing a $50 \%$ inhibition of cell growth $\left(\mathrm{IC}_{50}\right)$ were determined graphically using Easy Plot software for each experiment.

\section{Supporting Information}

The ${ }^{1} \mathrm{H}$ and ${ }^{13} \mathrm{C}$ NMR spectra of compounds $\mathbf{1 - 5}$ are available in the supporting information.

\section{Acknowledgments}

We are grateful to University Grants Commission (UGC)-Rajiv Gandhi National Fellowship (RGNF), New Delhi, for a research fellowship. Thanks are due to Dr. Sunil Varughese CSIR-NIIST for singlecrystal X-ray analysis. We thank Mrs. S. Viji and Mrs. Saumini Mathew of CSIR-NIIST for recording the mass and NMR spectra. 


\section{Conflicts of Interest}

The authors declare that they have no conflict of interest.

\section{References}

[1] Ibrahim TA, El-Hela AA, El-Hefnawy HM, Al-Taweel AM, Perveen S. Chemical composition and antimicrobial activities of essential oils of some coniferous plants cultivated in Egypt. Iran J Pharm Res 2017; 16: 328-337

[2] Simpson MG. Evolution and diversity of woody and seed plants. Plant Syst 2010; 129-162

[3] Farjon A. A Monograph of Cupressaceae and Sciadopitys. Richmond, Surrey, UK: Royal Botanic Gardens Press, Kew; 2005

[4] Long PK, Trang NTP, Averyanov LV, Loc PK. Molecular characterization of Calocedrus rupestris Aver., H.T. Nguyen \& L. K. Phan, 2008 (Cupressaceae) based on ITS1 partial sequence. Genet Mol Res 2011; 10: 3702-3711

[5] Yen PL, Wu CL, Chang ST, Huang SL, Chang HT. Antioxidative lignans from phytochemical extract of Calocedrus formosana florin. BioResources 2012; 7: 4122-4131

[6] Chang HT, Cheng YH, Wu CL, Chang ST, Chang TT, Su YC. Antifungal activity of essential oil and its constituents from Calocedrus macrolepis var. formosana Florin leaf against plant pathogenic fungi. Bioresour Technol 2008; 99: 6266-6270

[7] Hsien CL, Tseng MH, Pan RN, Chang JY, Kuo CC, Lee TH, Kuo YH. Labdanecaryophyllic acid, a novel cytotoxic C35 terpenoid from Calocedrus macrolepis var. formosana. Tetrahedron Lett 2011; 52: 515-517

[8] Wu XD, Wang SY, Wang L, He J, Li GT, Ding LF, Gong X, Dong LB, Song LD, Li Y, Zhao QS. Labdane diterpenoids and lignans from Calocedrus macrolepis. Fitoterapia 2013; 85: 154-160

[9] Tsai CC, Chen C], Tseng HW, Hua KF, Tsai RY, Lai MH, Chao LK, Chen ST. Cytomic screening of immuno-modulating activity compounds from Calocedrus formosana. Comb Chem High Throughput Screen 2008; 11: 834-842

[10] Hsu KP, Tu SH, Su YC, Ho CL. Chemical composition and antimicrobial activity against food-borne pathogens of Calocedrus formosana heartwood essential oil. Nat Prod Commun 2021; 16: 1-8

[11] Chiang YM, Liu HK, Lo JM, Chien SC, Chan Y, Lee TH, Su J-K, Kuo Y-H. Cytotoxic constituents of the leaves of Calocedrus formosana. J Chinese Chem Soc 2003; 50: 161-166

[12] Fang JM, Hsu KC, Cheng YS. Lignans from leaves of Calocedrus formosana. Phytochemistry 1989; 28: 3553-3555

[13] Chao KP, Hua KF, Hsu HY, Su YC, Chang ST. Anti-inflammatory activity of sugiol, a diterpene isolated from Calocedrus formosana bark. Planta Med 2005; 71: 300-305

[14] Zavarin E, Anderson AB. Extractive components from Incense-cedar heartwood (Libocedrus decurrens Torrey) I. Occurrence of carvacrol, hydrothymoquinone, and thymoquinone. J Org Chem 1955; 20: 82-88

[15] Zavarin E, Anderson AB. Extractive components from Incense-cedar heartwood (Libocedrus decurrens Torrey) II. Occurence and synthesis of p-methoxythymol and p-methoxycarvacrol, two new phenolic compounds. J Org Chem 1955; 20: 443-447

[16] Zavarin E, Anderson AB. Extractive components from Incense-cedar heartwood (Libocedrus decurrens Torrey). III. Occurence of libocedrol, a new phenolic ether, and its $\mathrm{p}$-methoxythymol addition complex. J Org Chem 1955; 20: 788-796

[17] Veluthoor S, Li S, Kelsey RG, Dolan MC, Panella NA, Karchesy J. Two new diterpene phenols from Calocedrus decurrans. Nat Prod Commun 2010; 5: 519-522
[18] Von Rudloff E. The leaf oil terpene composition of Incense cedar and coast redwood. Can J Chem 1981; 59: 285-287

[19] Veluthoor S, Kelsey RG, González Hernández MP, Panella N, Dolan M, Karchesy J. Composition of the heartwood essential oil of Incense cedar (Calocedrus decurrens Torr.). Holzforsch Int J Biol Chem Phys Technol Wood 2011; 65: 333-336

[20] Garcia G, Tissandie L, Filippi J], Tomi F. New pinane derivatives found in essential oils of Calocedrus decurrens. Molecules 2017; 22: 921

[21] Manter DK, Kelsey RG, Karchesy JJ. Antimicrobial activity of extractable conifer heartwood compounds toward Phytophthora ramorum. J Chem Ecol 2007; 33: 2133-2147

[22] Anderson AB, Schcffer TC, Duncan CG. The chemistry of decay resistance and its decrease with heartwood ageing in Incense cedar. Holzforsch Int J Biol Chem Phys Technol Wood 1963; 17: 1-5

[23] Dolan MC, Dietrich G, Panella NA, Montenieri JA, Karchesy J]. Biocidal activity of three wood essential oils against Ixodes scapularis (Acari: Ixodidae), Xenopsylla cheopis (Siphonaptera: Pulicidae), and Aedes aegypti (Diptera: Culicidae). J Econ Entomol 2007; 100: 622-625

[24] Moerman DE. Native American Ethnobotany. Oregon: Timber Press; 1998

[25] Ivankovic S, Stojkovic R, Jukic M, Milos M, Milos M, Jurin M. The antitumor activity of thymoquinone and thymohydroquinone in vitro and in vivo. Exp Oncol 2006; 28: 220-224

[26] Xuan TD, Chung IM, Khanh TD, Tawata S. Identification of phytotoxic substances from early growth of barnyard grass (Echinochloa crusgalli) root exudates. J Chem Ecol 2006; 32: 895-906

[27] Mahmoud AA, Ahmed AA. $\alpha$-Pinene-type monoterpenes and other constituents from Artemisia suksdorfii. Phytochemistry 2006; 67: 2103-2109

[28] Hammami S, Elshamy Al, Mokni R El, Snene A, Iseki K, Dhaouadi H, Okamoto Y, Suenaga M, Noji M, Umeyama A, Asakawa Y. Chemical constituents of the aerial parts of Daucus carota subsp. hispidus growing in Tunisia. Nat Prod Commun 2019; 14: 1-6

[29] Majdalawieh AF, Fayyad MW, Nasrallah GK. Anticancer properties and mechanisms of action of thymoquinone, the major active ingredient of Nigella sativa. Crit Rev Food Sci Nutr 2017; 57: 3911-3928

[30] Ahmad A, Mishra RK, Vyawahare A, Kumar A, Rehman MU, Qamar W, Khan AQ, Khan R. Thymoquinone (2-Isoprpyl-5-methyl-1, 4-benzoquinone) as a chemopreventive/anticancer agent: chemistry and biological effects. Saudi Pharm J 2019; 27: 1113-1126

[31] Samarghandian S, Azimi-Nezhad M, Farkhondeh T. Thymoquinoneinduced antitumor and apoptosis in human lung adenocarcinoma cells. J Cell Physiol 2019; 234: 10421-10431

[32] Imran M, Rauf A, Khan IA, Shahbaz M, Qaisrani TB, Fatmawati S, Abu-Izneid T, Imran A, Rahman KU, Gondal TA. Thymoquinone: a novel strategy to combat cancer: a review. Biomed Pharmacother 2018; 106 : 390-402

[33] Yang J, Kuang XR, Lv PT, Yan XX. Thymoquinone inhibits proliferation and invasion of human nonsmall-cell lung cancer cells via ERK pathway. Tumor Biol 2015; 36: 259-269

[34] Banerjee S, Azmi AS, Padhye S, Singh MW, Baruah JB, Philip PA, Sarkar FH, Mohammad RM. Structure-activity studies on therapeutic potential of thymoquinone analogs in pancreatic cancer. Pharm Res 2010; 27: 1146-1158

[35] Joseph MM, Aravind SR, Varghese S, Mini S, Sreelekha TT. PST-Gold nanoparticle as an effective anticancer agent with immunomodulatory properties. Colloids Surfaces B Biointerfaces 2013; 104: 32-39

[36] Joseph MM, Aravind SR, George SK, Raveendran Pillai K, Mini S, Sreelekha TT. Galactoxyloglucan-modified nanocarriers of doxorubicin for improved tumor-targeted drug delivery with minimal toxicity. | Biomed Nanotechnol 2014; 10: 3253-3268 